\title{
Legal Protection for Children Based on Law Number 17 of 2016
}

\author{
Krisna Murti ${ }^{1}$, Riswadi ${ }^{2}$ \\ Borobudur University ${ }^{1,2}$ \\ \{krisnaunboro@gmail.com ${ }^{1}$, riswadi@borobudur.ac.id $\left.{ }^{2}\right\}$
}

\begin{abstract}
Children are objects that are vulnerable to many violations of the law. Starting from deprivation of liberty, bullying, child trafficking, violence to sexual abuse. This paper discusses how the state exists through Law Number 17 of 2016 regarding legal protection for children, as part of Indonesian citizens. Through a normative approach and extracting literature data, it was found that based on applicable laws, the state guarantees that children are properly protected by law. The state guarantees legal protection for children's rights, exploitation, child welfare, deprivation of children's freedom, and protection from violence.
\end{abstract}

Keywords: Children; Legal Protection; Child Protection

\section{Introduction}

Child protection cases come with complex problems. It cannot be denied that the complexity of child protection issues in Indonesia is increasing in quality and quantity. Efforts to fight for child protection give birth to policies and laws that are in favor of the best interests of children. This struggle has taken a long way along with the ebb and flow of various interests and the multi-crisis situation in Indonesia. This is part of the long history of the journey of child protection in Indonesia. Various forms of violence against children, often occur throughout Indonesia, with reporting explicitly and repeatedly.[1] Various cases that have arisen have even involved people with the authority to protect children. Therefore, Indonesia is in an emergency phase of child protection.

Several cases of violence involving children actually made it even more serious because they indicated that it was committed by the legal authorities themselves. It takes various forms, for example a child who is confronted as a perpetrator of a crime of theft is enforced harshly. The officials concerned often forget that even though the child is in the status of a suspect, he is still at the age of a child who has special rights and needs to be protected.[2] Another case, Brigadier PB, a member of the Sat Intelkam Police, Melawi Police, killed his two biological children aged 5 years and 3 years at the Melawi Police hostel on Friday morning by mutilation, 26 February 2016, at 00.15 WIB.[3] Whatever the reasons and motives, in this case the child has become a victim.

Fun or unpleasant events will be engraved in children's memories and even their subconscious and will affect their psyche. The psychological effects can make children feel comfortable, happy, but also can cause trauma to the children to affect their personality.[4] It 
is in this condition that adults often forget that the adult phase that is currently being experienced goes through the phase of being a child as well. If we actually look at the history of natural law, it is the history of mankind in its efforts to determine absolute justice and the history of the failure of mankind in this endeavor.[5] In the process of growing children will learn from their existing life experiences, both good experiences and bad experiences.

Furthermore, children who are the nation's next generation should receive protection from their closest people, society and even the state. The government needs to be committed to making children a top priority in development. Therefore, all efforts need to be directed at quality human development, starting with a more serious respect and attention to children. These concrete efforts include creating an environment that prioritizes child protection, living up to values and traditions that promote children's dignity, and exploring and mobilizing resources to support the implementation of child protection.

\section{Content and Discussion}

Children are human resources who have the potential to carry on the aspirations of the Indonesian nation.[6] In their development phase, children need guidance physically, socially, and mentally in a gradual and balanced manner. Children are very unique individuals and have distinctive characteristics. Like adults, children can also act on their own feelings, thoughts, and will. In some ways, children are even more sensitive to sensitive things than adults. The growth and development of children is much influenced by their environment. Children can even commit acts or actions that are out of control, they can commit criminal acts so that they violate the law.

Baru Riau was declared negligent and deliberately did not care for children properly. It was revealed that there was a lot of garbage scattered around the orphanage and that there were lots of expired milk and food. This case was revealed to the public when one of the children, M Zikli (18 months) died in the hospital after experiencing a fever and from his mouth worms came out.[3] There are also many other tragic cases related to children who take out the conscience of the Indonesian people. How vulnerable are children to receive violent treatment.

Children from the time of their womb to birth have the right to life and freedom and receive good protection from their parents, family, community, nation and state. It is clear that no one can take away the right to life and freedom.[4] Children who are still in the womb have received the right of protection from the government. Therefore, the act of abortion is subject to strict legal sanctions. Children get protection both nationally and internationally. Children are universally protected in the Universal Declaration of Human Rights (UDHR) and the International on Civil and Political Rights (ICPR).[7]

The human rights given to children are different from those of adults. This is because children from the time they are still in the womb, are born, grow and develop until they become adults, are still not independent and require special treatment. The special treatment referred to is related to treatment in fulfilling physical, educational, skills, security and spiritual needs. This special treatment gets legal protection. Law Number 17 of 2016 concerning Amendments to Law Number 23 of 2002 concerning Child Protection reveals that children are an inseparable part of human survival and the sustainability of a nation and state. Later it is hoped that children will be able to be responsible for the sustainability of the nation and state. 
Every child needs to have the same and the widest possible opportunity to grow and develop optimally, both physically, mentally and socially. For this reason, it is necessary to make protection efforts to realize the welfare of children by providing guarantees for the fulfillment of their rights without discriminatory treatment.[8] Child protection efforts need to be implemented as early as possible, from in the womb until the child is 18 years old. Comprehensive child protection is based on:

a. Non-discrimination

b. Best interests of the child

c. Right to life, survival

d. Respect for children's opinions

In carrying out the guidance, development and protection of children, it is necessary to play the role of the community, either through child protection agencies, religious institutions, non-governmental organizations, social organizations, the business world, the mass media, or educational institutions.[9]

\subsection{Protection of Children's Rights in Law Number 17 of 2016 concerning Child Protection}

Providing protection to children is the right action because children are categorized as vulnerable groups. The children referred to are not only those who hold the status of Children with Special Needs but apply to all children in the world. The United Nations (UN) Committee on economic, social and cultural rights also identifies children as a vulnerable group. Protection of children is very important because violations of child protection are essentially violations of human rights. In addition, violations of children's rights can be a very big barrier to the survival and development of children. Children can experience violence, exploitation, neglect and other mistreatment. Children will be at risk of experiencing a shorter life, having poor mental and physical health, experiencing problems related to education (including dropping out of school), having poor parenting skills, being homeless, being expelled from their place of residence, and being homeless .

On the other hand, successful protective measures will increase children's chances of growing up physically, mentally, confidently, and less likely to abuse or exploit others, including their own children.[10] Children must be protected so that they do not become victims of acts of violence perpetrated by anyone (individuals or groups, private or government organizations) either directly or indirectly.[11] The child protection law regulates a variety of matters including the problem of children in conflict with the law, children from minority groups, children of victims of economic and sexual exploitation, children who are trafficked, children victims of riots, children who become refugees, to children in situations of armed conflict.

In Indonesia, the first regulation related to child protection is Law No.23 of 2002 concerning Child Protection. This law is deemed ineffective in protecting children from the rampant crimes against children in society, especially sexual crimes. Because of that, there were changes to the Law and the issuance of Law no. 35 of 2014 which seeks to reinforce criminal sanctions and fines for perpetrators of crimes against children. This is intended to provide a deterrent effect on the perpetrator and encourage concrete steps for physical, psychological and social recovery of child victims of crime. In its development, it seems that Law No.35 of 2014 has not significantly reduced the rate of crimes and sexual violence against children. The government then issued Perppu No. 1/2016 which was later stipulated as Law No.17 of 2016 which contained not only burdensome criminal sanctions for criminals but 
also prevention of violence against children. In this law, the government adds to the basic punishment in the form of death penalty, life sentence, and additional punishment in the form of announcing the identity of the perpetrator. The government also conveyed that there are penalties in the form of chemical castration, installation of electronic detection devices and rehabilitation for perpetrators.

a. Protection of children's rights based on Law Number 17 of 2016 concerning Child Protection, which includes:

b. Protection of children's rights to education by providing adequate facilities.

c. Protection of children's rights to grow healthy and develop by providing adequate care and nutrition.

d. Protection of children's rights to get a decent life by providing facilities and good moral guidance in behavior.

e. Protection of children's rights to gain freedom of having a belief by giving freedom to worship according to religion and belief.

With the existence of the Child Protection Law, it is hoped that every child in Indonesia can feel protected and their existence is increasingly being cared for by parents and the community.

\subsection{Barriers to the implementation of Law No.17 of 2016}

The Child Protection Law is a point of hope for children, especially in facing injustice from adults. Through the Child Protection Law, the Indonesian state emphasizes criminal sanctions for perpetrators of sexual crimes. The Child Protection Act also regulates preventive measures as steps to minimize crimes against children. The implementation of the Child Protection Law has many challenges. Looking further, this law does not fully represent the defense of the child himself. As a rule that aims to protect children's rights, Law Number 17 of 2016 focuses more on dealing with criminals against children only. Law enforcers only impose basic sanctions, whether to imprisonment, death penalty or castration (perpetrators of sexual crimes). Meanwhile, the rights of children as victims of crime, such as compensation, receiving assistance or supervision facilities, were not discussed.

The rise of crimes that have the potential to threaten children shows that law enforcement of the Child Protection Law in Indonesia is still not maximal.[12] The strengthening of the roles of several parties in law enforcement needs to be continuously evaluated by the related parties. First, law enforcement officers. As the front guard, law enforcement officers must be serious about investigating every crime against children. Do not let the law become a commodity that is easily offered and even traded. In the law enforcement process, every incident must be disclosed in a transparent, wise and impartial manner as Pancasila values. Second, community institutions. Crimes against children have been declared as extraordinary crimes, therefore anyone who is aware of crimes against children should report them. Third, social workers, namely those who have activities to realize social functions through interaction with the community so that they know exactly what the social environment situation is among them.

In an effort to create comprehensive child protection, it is inseparable from the obstacles faced in the implementation of the protection of children's rights. The obstacles that arise in the implementation of child protection in the implementation of Law Number 17 of 2016 are:

a. There are differences in the understanding of child protection, which results in people not wanting to participate. 
b. Lack of willingness to prioritize children's interests over personal interests, as a result the community does not feel obliged to participate in developing children's abilities to protect themselves properly.

c. The absence of cooperation between agencies, agencies, public and private organizations in the past is sustainable at this time, and this ugliness will probably continue if it is not dealt with now.

d. The absence of a guarantee of child protection in strict statutory regulations regarding child protection must be implemented in a concrete manner.

\section{Conclusion}

Every child needs to have the widest possible opportunity to grow and develop optimally, whether physically, mentally or socially. For this reason, it is necessary to make protection efforts to realize the welfare of children by providing guarantees for the fulfillment of their rights without discriminatory treatment. It can be understood that the protection of children's rights based on Law Number 17 of 2016 concerning Child Protection is a serious effort by the government to be able to respect and protect the existence of the nation's successor. The protection provided includes protection for life, growth and development, protection for education, protection for morals and protection for children's religions and beliefs. In law enforcement for child protection, it is found that the obstacles faced are related to the understanding of parents who often use punishment as a form of educating children, the community lacks ownership and considers that it is the child's family that is obliged to protect the child, there is no cooperation between agencies, bodies. , government and private organizations in the past that are sustainable at this time. This is a joint evaluation so that the fulfillment of children's rights and child protection can be pursued.

\section{Reference}

[1] Choky Ramadhan, "Reformasi Hukum Kekerasan Seksual," Kompas. .

[2] Reza Indragiri Amriel, Ketika Hukum Abai Hak Anak. Padang Ekspress.

[3] "5 Cerita Pilu Kekerasan Anak yang Berakhir Tragis - News Liputan6.com.".

[4] Laurensius Arliman S, Selamatkan Anak Melalui Penyuluhan Hukum. Posmetro Padang.

[5] Soetikno, Filsafat Hukum (Bagian II), Cetakan Kesepuluh. (Jakarta: PT. Pradnya Paramita, 2008.

[6] B. Harefa, Kapita Selekta Perlindungan Hukum Bagi Anak. Yogyakarta: CV. Budi Utama, 2019.

[7] Abussalam R. dan Adri Desasfuryanto, Hukum Perlindungan Anak. Jakarta: PTIK, 2016.

[8] M. T. Makarao, Hukum Perlindungan Anak Dan Penghapusan Kekerasan Dalam Rumah Tangga. Jakarta: Rineka Cipta, 2014.

[9] Candra Irawan, "Perlindungan Anak dan Hambatan dalam Pelaksanaannya Menurut Undang-undang Nomor 17 Tahun 2016 Tentang Perlindungan Anak," Universitas Muhammadiyah Palembang, 2019.

[10] Rika Saraswati, Hukum Perlindungan Anak di Indonesia. Bandung: Citra Aditya Bakti, 2015. 
[11] Maidin Gultom, Perlindungan Hukum Terhadap Anak dan Perempuan. Bandung: Refiak Aditama, 2012.

[12] "Implementasi Undang-Undang Nomor 17 Tahun 2016 tentang Perlindungan Anak novumpers.". 